\title{
Posterior composites - a challenge for practitioners
}

\author{
Compozitele posterioare - o provocare continuă pentru practicieni
}

\section{Andreea Cândea, Daniela Condor, Alexandra Roman, Cristina Micu, Andrada Şoancă}

Universitatea de Medicină şi Farmacie „Iuliu Haţieganu“, Cluj-Napoca, România

\begin{abstract}
Presently, at least half of posterior direct restorations rely on resin composite materials. The resin composite market is highly competitive between manufacturers providing practitioners with a vast choice from an array of similar product types.

The aim of the present article is to provide practitioners an updated view on the resin composites presently available, which could represent the theoretical basis for choosing this material type for different clinical purposes mainly focused on restoring posterior teeth. A significant progress in the composition of resin composites is represented by the improvement of the filler system in order to enhance mechanical properties and remineralizing potential, as well as to provide a cariostatic or anti-bacterial effects. Some clinical factors play an important role in restoration longevity and causes of failure such as: the tooth type, the number of restored teeth per patient, the type of the substrate on which the composite is placed, some demographic, socioeconomic and behavioral variables of the patient. It is generally acknowledged that the operator ability is probably the most important factor in the longevity of a dental restoration. Placement of direct composite restorations (mostly in class II cavities) on posterior teeth rests a highly demanding restorative procedure. Technique-related aspects of posterior restorations rely on the knowledge and sufficient skills of the operator.
\end{abstract}

Keywords: dental resin-based composite, restoration, nanocomposite, filler

\section{REZUMAT}

Aproximativ jumătate din obturaţiile plasate pe dinţii posteriori sunt din materiale compozite. La ora actuală, piaţa compozitelor dentare este extrem de competitivă, iar producătorii furnizează practicienilor stomatologi o gamă largă de produse similare, ceea ce poate îngreuna alegerea.

Scopul acestui articol este de a furniza practicienilor o trecere în revistă actualizată a materialelor compozite actuale, ceea ce poate constitui baza teoretică pentru alegerea unui material compozit în funcţie de scopul clinic, cu particularizarea compozitelor pentru reconstituirea dinţilor posteriori. Un progres important în compoziţia materialelor compozite dentare este reprezentat de îmbunătăţirea umpluturii anorganice pentru augmentarea proprietăţilor mecanice şi a potenţialului de remineralizare, dar şi pentru asigurarea unui efect cariostatic sau antibacterian. O serie de factori influenţează longevitatea restauraţiilor compozite posterioare, cum ar fi: tipul de dinte, numărul dinţilor restauraţi per pacient, tipul de substrat pe care se plasează compozitul, unele variabile demografice, socio-economice sau comportamentale ale pacientului. Poate cel mai important factor care influenţează longevitatea obturaţiilor este abilitatea practicianului. Plasarea restauraţiilor compozite directe pe dinţii posteriori (mai ales de clasa a II-a) rămâne o manoperă extrem de solicitantă şi pretenţioasă. Aspectele tehnice ale plasării restaurărilor compozite posterioare depind de buna informare a practicianului şi de abilităţile acestuia.

Cuvinte cheie: răşini compozite, restaurare, nanocompozite, umplutură

\section{INTRODUCERE}

Amalgamul a fost utilizat pe scară largă pentru restaurarea dinților posteriori. Cu toate că amalgamul are proprietăți mecanice bune şi longevitate crescută şi cu toate că este cel mai ,îngăduitor“ ma- terial utilizat în stomatologie, el este asociat cu numeroase neajunsuri (1). Astfel, a fost necesară găsirea unor materiale alternative pentru obturarea dinţilor posteriori. În prezent, cel puțin jumătate dintre restaurările directe ale dinţilor posteriori se 
realizează cu ajutorul materialelor compozite (răşini compozite) (2). Competiţia mare dintre producătorii de materiale compozite le oferă practicienilor o varietate largă de produse relativ similare. Cunoaşterea compoziției şi a proprietăţilor materialelor compozite poate ajuta practicianul în luarea deciziei clinice de alegere a soluției restauratoare. Prezentul articol îşi propune să ofere practicienilor o viziune actualizată asupra materialelor compozite disponibile în prezent, care ar putea reprezenta baza teoretică pentru alegerea tipului de material compozit pentru diferite cazuri clinice de restaurare a dinților posteriori. Un alt articol va conține informații structurate sub formă de sfaturi clinice privind restaurarea de succes a dinților posteriori, pentru a facilita obținerea de rezultate clinice performante.

Materialele compozite se disting prin diferențele de compozitiie care sunt particular adaptate indicațiilor specifice: restaurare, sigilare, restaurări provizorii, cimenturi etc. Aceste materiale se aseamănă între ele prin aceea că toate sunt compuse din trei faze distincte, care au propriul rol în dictarea proprietăților materialului: o matrice polimerică, umplutura anorganică cu rol de ramforsare şi un agent de cuplare silanic pentru legarea umpluturii cu matricea. Alte substanțe chimice sunt incluse pentru a iniţia sau modula polimerizarea indusă de lumină a matricei organice pentru a forma rețele polimerice reticulate (3). În ultimii ani au fost realizate progrese remarcabile în ceea ce priveşte performanțele clinice ale compozitelor dentare. Fiecare componentă a compozitelor reprezintă o oportunitate pentru îmbunătățirea de ansamblu a compoziției şi proprietăților materialului (4), aspect care a fost exploatat la maximum de către producători.

\section{Compoziția materialelor compozite utilizate în mod curent}

Componentele organice cele mai frecvente din structura materialelor compozite sunt reprezentate de 2,2 - bis (4-(2-hidroxi-3-metacriloxypropoxy) fenil-propan) (bis-GMA) şi uretan dimetacrilat (UDMA), ca monomeri principali. Alți monomeri de bază utilizați în compozitele curente sunt incluşi ca monomeri diluați şi sunt reprezentați de trietilenglicol dimetacrilat (TEGDMA), etoxilați Bisfenol-A-dimetacrilat (bis-EMA), dimetacrilat decanediol (D3MA), bis(metacriloxymethil) tricylodecane şi tetrametacrilat uretan (UTMA) (5).

Un progres semnificativ a fost reprezentat de dezvoltarea unor noi monomeri care să fie incluşi în structura compozitelor, care reduc contracția şi stresul de polimerizare. Astfel, sistemul siloranic tip epoxy utilizat de către Filtek Silorane LS ${ }^{\circledR}(3 \mathrm{M}$ ESPE) se asociază cu o contracție mai mică de priză decât răşinile bazate pe dimetacrilați. UDM modificat cu răşină DX511 de la Dupont, care se găseşte în materialul Kalore ${ }^{\circledR}(\mathrm{GC})$, reduce contracția de priză datorită greutății sale moleculare mari comparativ cu bis-GMA şi UDMA. O moleculă uretanică alternativă este monomerul uretan tricyclodecane (TCD) (6), care este regăsit în compozitul Venus Diamond ${ }^{\circledR}$ (HeraeusKulzer). Această moleculă a demonstrat un stres mai redus de polimerizare decât alte materiale datorită vâscozității sale reduse care nu mai necesită includerea de monomeri diluanți suplimentari (7). Monomerii acizi dimerici din materialul N'Durance ${ }^{\circledR}$ (Septodont) au o greutate moleculară relativ ridicată, dar şi o conversie crescută a dublelor legături de carbon, ceea ce se asociază cu o contracție de polimerizare mai mică decât sistemele pe bază de bis-GMA $(8,9)$.

În încercarea de a depăşi problemele create de contracția de polimerizare a materialelor compozite convenţionale, s-a dezvoltat o nouă clasă de materiale şi anume ceramicile modificate organic (Ormoceri) (10). Având un coeficient termic de expansiune similar cu cel al dintelui natural, aceste materiale au fost create sub forma unui nou polimer organic-anorganic reticulat tridimensional, sintetizat din uretani multifuncționali şi tioeter(met)acrilat alcoxisilani, ca şi precursor sol-gel. Grupările de alcoxisilil ale silanului permit formarea unei rețele anorganice Si-O-Si prin reacții de hidroliză şi policondensare. Grupările metacrilice sunt disponibile pentru polimerizarea fotochimică.

Compoziția şi cantitatea umpluturii anorganice influențează profund proprietățile mecanice ale materialelor compozite, reduc conținutul de monomer şi, prin urmare, contracţia de polimerizare, optimizează transluciditatea, opalescența, radioopacitatea şi îmbunătățesc proprietățile de manipulare şi lustruire. În final, interfaţa umplutură-răşină serveşte ca şi punte de legătură prin cuplarea fragmentelor polimerizabile de suprafaţa particulelor. Umpluturile convenționale sunt reprezentate de cuarț, dioxid de siliciu coloidal, sticlă de siliciu pe bază de bariu, stronțiu şi zirconiu (5). Cele mai importante modificări ale sistemelor compozite comerciale s-au făcut prin îmbunătătirea sistemului de umplutură. Variațiile de mărime, morfologie, cantitate, volum, distribuție sau compoziție chimică ale umpluturii au creat o mare varietate de categorii de materiale compozite. Clasificarea compozitelor dentare a evoluat de-a lungul anilor, dar în general 
aceasta s-a concentrat pe mărimea, conținutul şi compoziția chimică a umpluturii. O clasificare bazată pe distribuția şi mărimea umpluturii recunoaşte unele clase de materiale compozite, având proprietăți cu importanță clinică, dar, totodată, nu reflectă compoziția, morfologia sau alte specificații ale umpluturii, cum ar fi încărcătura de răşină prepolimerizată. $\mathrm{O}$ evoluție relativ recentă în dezvoltarea compozitelor a modificat umplutura prin includerea de siliciu topit şi nanoparticule de fosfat dicalcic şi tetraciclină pentru a îmbunătăți proprietățile mecanice şi potențialul de remineralizare bazat pe eliberarea de calciu şi fosfat (11). Remineralizarea poate fi promovată de eliberarea lentă a ionilor de calciu şi fosfat, urmată de precipitarea noilor minerale calciu-fosfat (12). Aceste materiale compozite pot fi mai rezistente şi mai dure, însă proprietățile optice nu sunt ideale, iar opacitatea lor necesită ca ele să fie autopolimerizabile. Includerea de umplutură pe bază de fluorură de calciu s-a asociat cu o eliberare crescută de fluor cu potențial efect cariostatic şi cu proprietăţi mecanice bune (12). Pot fi amintite două preparate conținând în umplutură compuşi fluorurați: Tetric Flow ${ }^{\circledR}$ şi Tetric N-Ceram ${ }^{\circledR}$ (Ivoclar). Totuşi, rezultatele clinice asociate utilizării compozitelor conținând fluor nu sunt concludente (13).

Alte arii de dezvoltare ale materialelor compozite se referă la încorporarea de alți agenți anti-bacterieni, cum ar fi clorhexidina (14), nanoparticule de oxid de zinc (15), nanoparticule de polietilenimină cuaternara de amoniu (16) şi 12-metacriloiloxidodecil brom piridină (Kuraray) (17).

\section{Clasificarea compozitelor dentare}

Materialele compozite se diferențiază în cabinet prin consistența lor, care depinde de compoziție. Răşinile compozite convenționale au o consistență chitoasă pentru a putea fi manipulate şi plasate cu un instrument de restaurare (spatulă sau obturator). Din această categorie fac parte Heliomolar $\mathrm{RO}^{\circledR}$ (Ivoclar), care are o concentrație a umpluturii de $46 \%$ (vol) şi Tetric Ceram ${ }^{\circledR}$ (Ivoclar) cu o concentrație a umpluturii de $60 \%$ (vol). Aceste materiale se disting de compozitele fluide, care sunt concepute pentru a fi distribuite în seringi foarte fine, care se manipulează în spații foarte înguste, pentru o adaptare sporită, dar şi de compozitele condensabile, care întâmpină o oarecare rezistență la condensarea cu un obturator, pentru a evita refluarea şi pentru realizarea contactelor interproximale ferme (3).

Compozitele fluide sunt de obicei realizate cu o vâscozitate mai scăzută prin reducerea conținutului de umplutură sau prin adăugarea de agenți modificanți, cum ar fi agenți tensioactivi, care îmbunătățesc fluiditatea, evitând totodată o scădere semnificativă a umpluturii, care ar reduce în mod semnificativ proprietățile mecanice şi ar creşte contracția (18).

Compozitele condensabile au o consistență mai vâscoasă prin modificarea distribuției granulometrice a umpluturii sau prin adăugarea altor tipuri de particule, cum ar fi fibrele, dar, în general, nu prin creşterea umpluturii globale (3). Din această categorie de materiale pot fi amintite Filtek Supre$\mathrm{me}^{\circledR}$ (3M ESPE), cu o concentrație a umpluturii de $59,5 \%$ (vol) şi SureFil ${ }^{\circledR}$ (Dentsply) cu o concentrație a umpluturii de $60-70 \%$ (vol).

Fiecare tip de material compozit din cele anterior menționate (convențional, fluid, condensabil) se distinge prin caracteristicile şi dimensiunea umpluturii.

Trecând în revistă evoluția tehnicilor de procesare a umpluturii anorganice, se observă că mărimea particulelor umpluturii, de obicei sticlă măcinată, a scăzut de la zeci de microni până la aproximativ $1 \mu \mathrm{m}\left(10^{-6}\right)$ (3). Microparticule de dimensiuni submicronice de $0,5-1,0 \mu \mathrm{m}$ sunt utilizate în unele materiale compozite comerciale. De exemplu, Kalore ${ }^{\circledR}$ (GC), Filtek LS ${ }^{\circledR}$ (3M ESPE) şi Aelite ${ }^{\circledR}$ (Bisco) conțin în umplutură şi particule submicronice pre-polimerizate obținute prin măcinarea compozitului polimerizat. Această modificare vizează reducerea stresului la polimerizare, îmbunătăţirea capacităţii de lustruire şi a proprietăţilor optice comparativ cu materialele hibride anterioare (19). Particulele prepolimerizate sunt polimerizate şi măcinate înainte ca materialul care le conține să fie polimerizat în cavitatea orală, astfel că particulelor pre-polimerizate le lipsesc situsurile de legare active şi sunt, deci, greu de silanizat, aşteptându-se o integrare mai deficitară în matricea răşinoasă (20). Nanoparticulele $\left(10^{-9}\right)$, introduse ințial cu efortul de a îmbunătăţi estetica materialelor, sunt astăzi folosite în unele materiale moderne, sub formă de nano-agregate, pentru augmentarea proprietăților mecanice şi, în special, a rezistenței (21). Umplutura de dimensiune nano, mai mică decât lungimea de undă a spectrului vizibil, reprezintă un avantaj suplimentar al compozitelor fotopolimerizabile, deoarece reduce refracția şi dispersia, ceea ce poate îmbunătăţi adâncimea de polimerizare (22).

În unele compozite convenționale, dimensiunea particulelor depăşeşte cu mult $1 \mu \mathrm{m}$ şi în mod normal este aproape de sau mai mare decât diametrul unui fir de păr uman (aproximativ $50 \mu \mathrm{m}$ ). Aceste 
materiale cu ,macroumplutură“ sunt rezistente, dar sunt dificil de lustruit şi nu îşi păstrează aspectul neted al suprafeței. Îmbunătățirea tehnicilor de frezare şi măcinare a dus la obținerea unor particule de umplutură de dimensiuni mai mici, microscopice, de aproximativ $40 \mathrm{~nm}$, care stau la baza materialelor compozite cu, ,microumplutură ${ }^{\text {“6 }}$. Ar fi fost mai corect ca aceste compozite cu, ,microumplutură“" să fie numite compozite cu ,nanoumplutură“', dar conceptul de nanotehnologie nu era recunoscut la acel moment (3). Aceste materiale au o capacitate bună de lustruire, dar au o rezistență scăzută din cauza conținutului mic de umplutură asociat suprafeței foarte mari a particulelor şi, deci, volumului mic de umplutură. În consecință, volumul umpluturii nu diferă față de compomerii fluizi şi este chiar mai mic comparativ cu cel din materialele compozite fluide.

În continuare s-au dezvoltat materiale ,hibride cu particule mici“", cu dimensiuni medii puțin mai mari de $1 \mu \mathrm{m}$, dar care conțin şi ,microumplutură“" reprezentată de silice pirogenă de $40 \mathrm{~nm}$ (3). Compozitele „microhibride“ au particule cu dimensiuni sub-micronice, cu o medie de 0,4-1,0 $\mu \mathrm{m}$ (3). Aceste materiale sunt considerate compozite universale cu aplicabilitate clinică, atât în zona anterioară, cât şi în cea posterioară, datorită proprietăților bune, atât mecanice, cât şi de lustruire. Cea mai recentă noutate este reprezentată de compozitele cu „nanoumplutură“", care conţin numai particule nanometrice. Compozitele ,nanohibride“ sunt, de fapt, compozite „microhibride“ care contin o cantitate crescută de nanoparticule. Termenul de compozite „nanohibride“ se referă la materialele care conțin o fracție de nanoparticule $(<100$ $\mathrm{nm})$ şi particule submicronice $(\leq 1 \mu \mathrm{m}$ cu o medie de $0,5-1,0 \mu \mathrm{m})(3)$. În general, este dificil de diferențiat compozitele „nanohibride“6 de cele „microhibride“. Compozitele ,nanohibride“ se aşteaptă să conțină o proporție mai mare de nanoparticule. S-a sugerat că proprietățile uşor mai slabe ale compozitelor „nanohibride“ comparativ cu „microhibridele“ se datorează încorporării de răşină pre-polimerizată (3).

\section{Proprietățile răşinilor compozite}

Popularitatea răşinilor compozite se datorează versatilității lor, calității estetice şi proprietăților mecanice bune, care duc la performanțe clinice convenabile (20). Pentru utilizarea în zona dinților posteriori, compozitele trebuie să aibă proprietăți mecanice excelente, rezistență crescută la uzură, la fractură, la stres, şi adeziune foarte bună (23).
Compozitele destinate dinților posteriori se recomandă a avea o rezistență la încovoiere $\geq 80 \mathrm{Mpa}$ (ISO 4049). Compozitul întăreşte structura dentară restantă (prin adeziunea performantă), evitând metodele mai invazive de restaurare, cum ar fi aplicarea unei coroane de înveliş (24).

Compozitele cu ,microumplutură“6 au cele mai slabe proprietăţi mecanice. Rezultatele clinice arată că utilizarea lor s-a asociat cu fracturarea obturațiilor de trei sau patru ori mai frecventă decât la utilizarea materialelor compozite convenționale (25), fapt care explică probabil eşecul catastrofal al compozitelor cu ,microumplutură“ în zonele posterioare (26). Pe de altă parte, s-a arătat că unele compozite cu „microumplutură“ ca Durafill ${ }^{\circledR}$ (Heraeus Kulzer) şi HeliomolarRO ${ }^{\circledR}$ (Ivoclar) au prezentat o uzură mai scăzută comparativ cu unii compomeri ca Dyract $\mathrm{AP}^{\circledR}$ (Dentsply), Compoglass $\mathrm{F}^{\circledR}$ (Ivoclar) sau compozite hibride ca Estilux Hybrid $^{\circledR}$ (Heraeus Kulzer), Charisma ${ }^{\circledR}$ (Heraeus Kulzer), Z100 ${ }^{\circledR}$ (3M ESPE), Tetric classic ${ }^{\circledR}$ (Ivoclar) (27).

Comparând unele compozite condensbile ca Solitaire $^{\circledR}$ (HeraeusKulzer), SureFil ${ }^{\circledR}$ (Dentsply) şi Alert $^{\mathbb{B}}$ (Pentron) cu un Ormocer condensabil Definite $^{\circledR}$ (Degussa) şi un compozit hibrid Tetric Ce$\operatorname{ram}^{\circledR}$ (Ivoclar), s-a observat că materialul Alert ${ }^{\circledR}$ prezintă cea mai mare rezistență la încovoiere, modul de elasticitate şi rezistenţă la fractură, însă cea mai mică rezistență la uzură, în timp ce compozitul Solitaire ${ }^{\circledR}$ prezintă opusul, având proprietăți mecanice slabe şi o mai bună rezistență la uzură. SureFil ${ }^{\mathbb{R}}$ prezintă proprietăţi mecanice mai bune şi rezistență la uzură mai mare decât compozitele Tetric Ceram $^{\circledR}$ şi Definite ${ }^{\circledR}(28)$. Proprietățile mecanice ale unor compozite condensabile (Alert ${ }^{\mathbb{B}}$, Solitai$\mathrm{re}^{\circledR}$, SureFil ${ }^{\circledR}$ ) sunt similare cu cele ale unor compozite hibride $\left(Z 100^{\circledR}\right)$ şi mai bune decât ale compozitului Solitaire ${ }^{\circledR}(29)$. Comportamentul şi proprietățile mecanice ale materialelor sunt mai degrabă influențate de sistemul de umplutură decât de categoria de materiale din care fac parte (28).

Compozitele cu ,nanoumplutură ${ }^{\text {“ }}$ au o absorbție crescută de apă, având ca rezultat degradarea interfeței matrice/umplutură, ceea ce afectează proprietățile mecanice în comparație cu un compozit „microhibrid“. Rezistențele la încovoiere şi la compresiune ale compozitelor ,hibride“ şi ,nanohibride" sunt similare.

Ormocerii s-au asociat cu o rată mai mică de uzură comparativ cu compozitele $(30,31)$ şi o contracție de priză egală cu cea a compozitelor, ,hibride“", în ciuda faptului că au un conţinut de încărcătură mai scăzut (32). Cu limitarea datorată unei 
testări reduse a compozitelor de tip ormocer, proprietățile mecanice ale acestora nu diferă de cele ale compozitelor „hibride“. Ormocerii recent dezvoltați aflați încă în stadiu experimental, sintetizați din tri-alkosilan dimetacrilat amină sau amidă şi care nu conțin diluant dimetacrilat, au avut modul de încovoiere evident îmbunătătit comparativ cu ormocerii clasici tip Definite ${ }^{\circledR}(33)$.

Un aspect important în ceea ce priveşte plasarea materialelor compozite se referă şi la caracteristicile lor de manipulare. Vâscozitatea este cea mai importantă caracteristică pentru compozitele fluide, iar studiile arată că vâscozitatea variază foarte mult între diferitele tipuri de firme producătoare, fără a exista însă o corelație între forma particulelor de încărcătură şi cu o corelație minimă cu volumul umpluturii (34). Cu toate acestea, compozitele sunt pseudoplastice, adică devin tot mai fluide atunci când sunt supuse forțelor de forfecare, cum ar fi atunci când sunt plasate cu ajutorul unei seringi. Rezistența la curgere a compozitului este legată de vâscozitate, însă proprietatea este mult mai complexă. O altă caracteristică a materialului compozit, de data aceasta subiectivă, este cea de lipire (de instrumente) şi ea poate influența mult opțiunea clinicianului. Capacitatea de lipire tinde să crească odată cu creșterea temperaturii de la $23^{\circ} \mathrm{C}$ la $27^{\circ} \mathrm{C}(35)$.

\section{Rata de succes a compozitelor în zona dinților posteriori şi factorii de influență}

Măsurarea succesului unui tratament restaurativ este puternic asociat cu longevitatea restaurației (36). Deşi testele de laborator pot furniza informații cu privire la longevitatea restaurărilor, performanțele pe termen lung ale acestor sisteme se evaluează prin studii clinice. Rezultate clinice furnizate de diferite cercetări sunt heterogene din cauza diferențelor de design experimental, abilităților operatorului sau caracteristicilor pacientului sau ale materialului (37).

Observarea pentru o perioadă de 5 ani, a unui grup de peste 30.000 de pacienți din SUA cu restaurări dentare a relevat o probabilitate de supraviețuire a restaurărilor de amalgam de $94 \%$. Pentru materialele compozite posterioare, rata a fost de 93\% (38). Datele pentru perioade mai mari de observație, între 1 an şi 10 ani, au raportat o rată anuală de eşec scăzută, de aproximativ $2 \%(39,40,41)$. Rata de înlocuire a restaurațiilor compozite la personalul de la US Navy şi Marină nu a fost aceeaşi cu cea pentru amalgam (42).

Datele din literatura de specialitate arată că cea mai comună cauză a eşecului materialelor compo- zite este fractura obturației, pentru perioade mai mici de 5 ani (43), fiind urmată de apariția cariilor secundare, pentru perioade de observare mai lungi $(43,44)$. Motivul principal pentru eşecul restaurațiilor plasate în cavități mari este fractura, pentru o perioadă de observare mai mare de 11 ani $(45,46)$.

Evaluarea corectitudinii unei restaurări compozite este complexă, deoarece apreciază parametrii mai subtili decât fractura sau caria secundară. US Public Health Service (USPHS) propune un set de criterii pentru a evalua succesul sau eşecul restaurațiilor de compozit. Aceste criterii evaluează colorația marginală, închiderea marginală, textura suprafeței, sensibilitatea postoperatorie şi cariile reicidive. Restaurațiile se clasifică în funcție de următoarele scoruri - Alpha - situație clinică ideală, Bravo - situație clinică acceptabilă şi Charlie situație clinică inacceptabilă (47). Un alt sistem de evaluare a fost propus de FDI.

O serie de factori clinici joacă un rol important în longevitatea sau eşecul unei restaurații de compozit. Mai multe studii au indicat faptul că poziția dintelui în cavitatea orală sau tipul dintelui afectează în mod direct longevitatea restaurațiilor. Astfel, restaurațiile pe premolari se comportă mai bine decât cele realizate la nivelul molarilor $(41,48,49)$. Riscul de eşec al unei restauraţii este de două ori mai mare la molari decât la premolari (49) şi de trei ori mai mare la molari mandibulari comparativ cu premolarii maxilari (48). În cazul restaurațiilor mari pe trei sau mai multe suprafețe nu au fost găsite diferențe între molari şi premolari în ceea ce priveşte rata de eşec (50).

Un risc crescut de eşec a fost raportat la pacientii cu un număr mare de restaurații $(51,49)$, probabil din cauza cario-receptivității crescute. Deşi dovezile sunt limitate, se pare că tipul pacienților şi mediul oral joacă un rol important în supraviețuirea restaurărilor dentare. Cario-receptivitatea crescută a pacienților are o influență majoră asupra longevităţii restaurațiilor $(52,50)$. Pacienții cu cario-receptivitate crescută prezintă un risc de două ori mare de eşec al restaurațiilor, decât pacienții cu cario-receptivitate scăzută (50).

Un alt factor care ar putea influența longevitatea sau eşecul unei restauraţii este comportamentul clinic al materialului de obturație $(49,40)$.

Tipul substratului pe care se aplică compozitul de restaurare influențează longevitatea. Folosirea unei baze de ionomer de sticlă sub o restaurare adezivă pare să scadă rata de supraviețuire comparativ cu restaurațiile total-etch, iar motivul principal de eşec este fracturarea $(49,41,48)$. Oricum, cavitățile profunde impun utilizarea unei obturații de bază. 
Este, în general, recunoscut faptul că îndemânarea operatorului este probabil factorul cel mai important în determinarea longevității restaurațiilor. Plasarea de restaurări compozite directe (mai ales cavități de clasa a 2-a) la nivelul dinţilor posteriori este o manoperă dificilă şi solicitantă. Tehnica de restaurare a dinţilor posteriori se bazează pe cunoştințele şi abilităţile operatorului. Dentiştii care lucrează eficient, realizează restaurații cu rată de supraviețuire mai mare decât cei care lucrează ineficient. Studenții fără experiență sunt mult mai des asociaţi cu eşecuri ale obturațiilor, decât studenții care au mai multă experiență (53).

Este foarte probabil ca obiceiurile vicioase, cum este bruxismul, să ducă la apariţia unei tensiuni între țesut dentar şi compozit, fapt ce duce pe termen lung la fractură. Diagnosticarea bruxismului nu este uşoară, iar instrumentele pentru diagnosticare nu sunt întotdeauna fiabile (54). Literatura de specialitate sugerează că rata de eşec este mai mare pentru restaurațiile mari şi că uzura continuă poate fi un motiv semnificativ de eşec pentru pacienții cu bruxism (55).

Sensibilitatea postoperatorie este un alt motiv de apreciere a eşecului. Sensibilitatea postoperatorie este mai repede asociată cu sistemul adeziv utilizat (56) sau cu tehnica utilizată (57).

Cerințele pacientului în ceea ce priveşte estetica este un alt factor care influențează longevitatea. Cerințele estetice mari duc la mai multe înlocuiri ale obturațiilor. Eşecul datorat cerințelor estetice ale compozitelor posterioare este foarte rar (52).

În plus faţă de variabilele clinice, legate de material sau de practician, o serie de variabile demografice, socio-economice şi comportamentale ale pacientului pot afecta longevitatea restaurărilor compozite posterioare. Cariile dentare sunt puternic asociate cu factori sociali de-a lungul vieții $(58,59,60)$, astfel că factorii sociali pot influența în mod indirect longevitatea restaurațiilor. $\mathrm{Cu}$ toate acestea, puține informații sunt disponibile pe acest subiect, iar cele mai multe studii privind longevitatea restauraţiilor au nevoie de monitorizare clinică. $(41,48,61)$. S-a observat o relaţie puternică între frecvenţa vizitelor de control şi timpul de supraviețuire al unei restaurații, dovedindu-se că restauraţiile care sunt mai frecvent urmărite au un timp de supraviețuire mai mare decât cele care sunt mai puțin frecvent monitorizate.

$\mathrm{Cu}$ toate că studiile in vitro au arătat că proprietățile materialelor compozite posterioare disponibile pe piață sunt diferite $(62,23,63,14)$, studiile clinice au descris doar puține diferențe în ceea ce priveşte comportamentul clinic al acestor materiale $(64,40)$.

\section{CONCLUZII}

Proprietățile materialelor de restaurare compozite sunt influenţate mai ales de calitatea şi cantitatea umpluturii. Pentru restaurarea dinţilor posteriori sunt recomandate compozitele micro- sau nano-hibride. O serie de factori legaţi de caracteristicile socio-economice sau comportamentale ale pacientului, dar şi de abilităţile practicianului, influențează longevitatea restauraţiilor compozite.

Mulțumiri. Această lucrare a fost realizată în cadrul Proiectului de Cercetare Doctorală susținut de Universitatea de Medicină şi Farmacie Iuliu Hațieganu, Cluj Napoca, Nr. contract 1300/10 din 13.01.2017.

Conflict of interest: none declared

\section{$\overline{\text { BIBLIOGRAFIE }}$}

1. Jackson R.D. Class II composite resin restorations: faster, easier, predictable. Br Dent J. 2016; 221(10):623-631.

2. Sadowsky S.J. An overview of treatment considerations for esthetic restorations: a review of the literature. J Prosthet Dent. 2006; 96(6):433-42.

3. Ferracane J.L. Resin composite-state of the art. Dent Mater $2011 ; 27: 29-38$.

4. Cramer N.B., Stansbury J.W., Bowman C.N. Recent advances and developments in composite dental restorative materials. J Dent Res. 2011; 90(4):402-16

5. Chen M.H. Update on dental nanocomposites. J Dent Res. 2010; 89(6):549-60.

6. Frauscher K.E., Ilie N. Degree of conversion of nano-hybrid resin-based composites with novel and conventional matrix formulation. Clin Oral Investig. 2013; 17(2):635-42.

7. Marchesi G., Breschi L., Antoniolli F. et al. Contraction stress of low-shrinkage composite materials assessed with different testing systems. Dent Mater. 2010; 26(10):947-53.

8. Lui H., Trujilo-Lemon M., Ge J., Stansbury J.W. Dental resins based on dimer acid dimethacrylates: a route to high conversion with low polymerization shrinkage. Compendium 2010; 31(Special Issue 2):1-4.

9. Bracho-Troconis C., Trujillo-Lemon M., Boulden J., Wong N. et al. Characterization of N'Durance: a nanohybrid composite based on new nano-dimer technology. Compend Contin Educ Dent. 2010; 31 Spec No 2:5-9.

10. Wolter H., Storch W., Ott H. New inorganic/organic copolymers(ORMOCER S) for dental application. Mat ResSocSymp Proc 1994; 346:143-149. 
11. Xu H.H., Moreau J.L., Sun L., Chow L.C. Novel CaF(2) nanocomposite with high strength and fluoride ion release. J Dent Res. 2010; 89(7):739-45.

12. Xu H.H., Weir M.D., Sun L. et al. Strong nanocomposites with $\mathrm{Ca}, \mathrm{PO}(4)$, and $\mathrm{F}$ release for caries inhibition. J Dent Res. 2010; 89(1):19-28.

13. Wiegand A., Buchalla W., Attin T. Review on fluoridereleasing restorative materials--fluoride release and uptake characteristics, antibacterial activity and influence on caries formation. Dent Mater. 2007; 23(3):343-62. Epub 2006 Apr 17.

14. Aljabo A., Abou Neel E.A., Knowles J.C., Young A.M. Development of dental composites with reactive fillers that promote precipitation of antibacterial-hydroxyapatite layers. Mater Sci Eng C Mater Biol Appl. 2016; 60:285-92

15. Sevinc B.A., Hanley L. Antibacterial activity of dental composites containing zinc oxide nanoparticles. J Biomed Mater Res B: Appl Biomater 2010; 94B:22-31

16. Beyth N., Yudovin-Farber I., Bahir R. et al. Antibacterial activity of dental composites containing quaternary ammonium polyethylenimine nanoparticles against Streptococcus mutans. Biomaterials. 2006; 27(21):39954002.

17. Ebi N., Imazato S., Noiri Y., Ebisu S. Inhibitory effects of resin composite containing bactericide-immobilized filler on plaque accumulation. Dent Mater. 2001; 17(6):485-91.

18. Bayne S.C., Thompson J.Y., Swift E.J. Jr et al. A characterization of first-generation flowable composites. J Am Dent Assoc. 1998; 129(5):567-77.

19. Ferracane J.L., Pfeifer CS, Hilton T.J. Microstructural features of current resin composite materials. Curr Oral Health Rep 2014;1:205-12.

20. Randolph L.D., Palin W.M., Leloup G., Leprince J.G. Filler characteristics of modern dental resin composites and their influence on physico-mechanical properties. Dent Mater. 2016; 32(12):1586-1599.

21. Curtis A.R., Palin W.M., Fleming G.J. et al. The mechanical properties of nanofilled resin-based composites: the impact of dry and wet cyclic pre-loading on bi-axial flexure strength. Dent Mater 2009; 25:188-97.

22. Fujita K., Ikemi T., Nishiyama N. Effects of particle size of silica filler on polymerization conversion in a light-curing resin composite. Dent Mater 2011; 27:1079-85.

23. Ilie N., Hickel R. Investigations on mechanical behaviour of dental composites. Clin Oral Investig. 2009; 13(4):427-38.

24. Opdam NJ, Roeters JJ, Loomans BA, Bronkhorst EM. Seven-year clinical evaluation of painful cracked teeth restored with a direct composite restoration. J Endod. 2008; 34(7):808-11.

25. Lambrechts P., Ameye C., Vanherle G. Conventional and microfilled composite resins. Part II. Chip fractures. J Prosthet Dent. 1982; 48(5):527-38.

26. Leinfelder K.F., McCartha C.D., Wisniewski J.F. Posterior composite resins. A critical review. J Ala Dent Assoc. 1985; 69(1):19-25.

27. Zantner C., Kielbassa A.M., Martus P., Kunzelmann K.H. Sliding wear of 19 commercially available composites and compomers. Dent Mater. 2004; 20(3):277-85.

28. Manhart J., Kunzelmann K.H., Chen H.Y., Hickel R. Mechanical properties and wear behavior of light-cured packable composite resins. Dent Mater. 2000; 16(1):33-40.

29. Knobloch L.A., Kerby R.E., Seghi R. et al. Fracture toughness of packable and conventional composite materials. J Prosthet Dent. 2002; 88(3):307-13.

30. Tagtekin D.A., Yanikoglu F.C., Bozkurt F.O. et al. Selected characteristics of an Ormocer and a conventional hybrid resin composite. Dent Mater. 2004; 20(5):487-97.
31. Yap A.U., Tan C.H., Chung S.M. Wear behavior of new composite restoratives. Oper Dent. 2004; 29:269-274.

32. Cattani-Lorente M., Bouillaguet S., Godin C.H., Meyer J.M. Polymerization shrinkage of Ormocer based dental restorative composites. Eur Cell Mater. 2001; 1:25-26.

33. Moszner N., Gianasmidis A., Klapdohr S. et al. Sol-gel materials 2. Light-curing dental composites based on ormocers of cross-linking alkoxysilane methacrylates and further nano-components. Dent Mater. 2008; 24(6):851-6.

34. Beun S., Bailly C., Devaux J., Leloup G. Rheological properties of flowable resin composites and pit and fissure sealants. Dent Mater. 2008; 24(4):548-55.

35. Ertl K., Graf A., Watts D., Schedle A. Stickiness of dental resin composite materials to steel, dentin and bonded dentin. Dent Mater. 2010; 26(1):59-66

36. Bücher K., Tautz A., Hickel R., Kühnisch J. Longevity of composite restorations in patients with early childhood caries (ECC). Clin Oral Investig. 2014; 18(3):775-82.

37. Hickel R., Roulet J.F., Bayne S. et al. Recommendations for conducting controlled clinical studies of dental restorative materials. Clin Oral Investig. 2007; 11(1):5-33.

38. Bogacki R.E., Hunt R.J., del Aguila M., Smith W.R. Survival analysis of posterior restorations using an insurance claims database. Oper Dent. 2002; 27(5):488-92.

39. Gaengler P., Hoyer I., Montag R. Clinical evaluation of posterior composite restorations: the 10-year report. J Adhes Dent. 2001; 3(2):185-94.

40. Pallesen U., Qvist V. Composite resin fillings and inlays. An 11-year evaluation. Clin Oral Investig. 2003; 7(2):71-9.

41. DaRosa Rodolpho P.A., Cenci M.S., Donassollo T.A. et al. A clinical evaluation of posterior composite restorations: 17 year findings. J Dent 2006; 34:427-35.

42. Laccabue M., Ahlf R.L., Simecek J.W. Frequency of restoration replacement in posterior teeth for U.S. Navy and Marine Corps personnel. Oper Dent. 2014; 39(1):43-9.

43. Brunthaler A., König F., Lucas T. et al. Longevity of direct resin composite restorations in posterior teeth. Clin Oral Investig. 2003; 7(2):63-70.

44. Nedeljkovic I., Teughels W., De Munck J. et al. Is secondary caries with composites a material-based problem? Dent Mater. 2015; 31(11):e247-77.

45. Van Dijken J.W. Direct resin composite inlays/onlays: an 11 year follow-up. J Dent. 2000; 28(5):299-306.

46. Van Nieuwenhuyzen J.P., D’Hoore W., Carvalho J., Qvist V. Long -term evaluation of extensive restoration in permanent teeth. J Dent 2003; 31:395-405.

47. Cvar J.F., Ryge G. Reprint of Criteria for the clinical evaluation of dental restorative materials. Clin Oral Invest 2005; 9:215-232.

48. DaRosa Rodolpho P.A., Donassollo T.A., Cenci M.S. et al. 22-year clinical evaluation of the performance of two posterior composites with different filler characteristics. Dent Mater 2011; 27:955-63.

49. Opdam N.J., Bronkhorst E.M., Roeters J.M., Loomans B.A. Longevity and reasons for failure of sandwich and total-etch posterior composite resin restorations. J Adhes Dent. 2007; 9(5):469-75.

50. Opdam N.J., Bronkhorst E.M., Loomans B.A., Huysmans M.C. 12-year survival of composite vs. amalgam restorations. J Dent Res. 2010; 89(10):1063-7.

51. Soncini J.A., Maserejian N.N., Trachtenberg F. et al. The longevity of amalgam versus compomer/composite restoration in posterior primary and permanent teeth:findings From New England Children's Amalgam Trial. J Am Dent Assoc 2007; 138:763-72. 
52. Demarco Flavio F., Marcos B. Correa, Maximiliano S. Cenci et al. Longevity of posterior composite restoration: Not only a matter of materials. Dental Materials 2012; 28:87-101.

53. Opdam N.J., Loomans B.A., Roeters F.J., Bronkhorst E.M. Five-year clinical performance of posterior resin composite restorations placed by dental students. J Dent. 2004; 32(5):379-83.

54. Abe S., Yamaguchi T., Rompré P.H. et al. Tooth wear in young subjects: a discriminator between sleep bruxers and controls? Int J Prosthodont. 2009; 22(4):342-50.

55. Ferracane J.L. Is the wear of dental composites still a clinical concern? Is there still a need for in vitro wear simulating devices? Dent Mater. 2006; 22(8):689-92.

56. Perdigão J., Dutra-Corrêa M., Castilhos N. et al. One-year clinical performance of self-etch adhesives in posterior restorations. Am J Dent. 2007; 20(2):125-33.

57. Perdigão J., Geraldeli S., Hodges J.S. Total-etch versus self-etch adhesive: effect on postoperative sensitivity. J Am Dent Assoc. 2003;134(12):1621-9.

58. Peres M.A., Peres K.G., de Barros A.J., Victora C.G. The relation between family socioeconomic trajectories from childhood to adolescence and dental caries and associated oral behaviours. J Epidemiol Community Health. 2007; 61(2):141-5.
59. Thomson W.M., Poulton R., Milne B.J. et al. Socioeconomic inequalities in oral health in childhood and adulthood in a birth cohort. Community Dent Oral Epidemiol. 2004; 32(5):345-53.

60. Thomson W.M. Dental caries experience in older people over time: what can the large cohort studies tell us? Br Dent J. 2004; 196(2):89-92.

61. Demarco F.F., Cenci M.S., Lima F.G. et al. Clas II composite restorationS with metallic and translucent matrices: 2-year follow-up findings. J Dent 2007; 35:231-7.

62. de Moraes R.R., Gonçalves Lde S., Lancellotti A.C. et al. Nanohybrid resin composites: nanofiller loaded materials or traditional microhybrid resins? Oper Dent. 2009; 34(5):551-7.

63. Schultz S., Rosentritt M., Behr M., Handel G. Mechanical properties and three-body wear of dental restoratives and their comparative flowable materials. Quintessence Int. 2010; 41(1):e1-10.

64. Krämer N., García-Godoy F., Frankenberger R. Evaluation of resin composite materials. Part II: in vivo investigations. Am J Dent. 2005; 18(2):75-81. 